\title{
Budzet zadaniowy a naruszenia dyscypliny finansów publicznych związane z wydatkami publicznymi
}

\begin{abstract}
Wojciech Bożek*
$W$ artykule omówiono zagadnienia zwiazane z instytucja wydatków publicznych ujętych $w$ budżecie zadaniowym $w$ kontekście postanowień ustawy o odpowiedzialności za naruszenie dyscypliny finansów publicznych. Autor dokonuje ogólnej analizy budżetu zadaniowego, jego celów i cech charakterystycznych, podkreślając, że w polskim porzadku prawnym istnieje potrzeba rozwinięcia zakresu przedmiotowego odpowiedzialności za naruszenie dyscypliny finansów publicznych. W aktualnym stanie prawnym utrudnione, a niekiedy nawet niemożliwe jest ukaranie osób odpowiedzialnych za nieprzestrzeganie zasad związanych $z$ dokonywaniem wydatków publicznych ujętych we wtaściwym budżecie zadaniowym.

Celem autora jest ukazanie wplywu braków definicyjnych $w$ ustawie o finansach publicznych, odnoszacych się do budżetu zadaniowego, na efektywność egzekwowania odpowiedzialności za naruszenie dyscypliny finansów publicznych. Należy bowiem mieć na uwadze, że ww. rozwiazania prawne maja charakter represyjny $i$ zakazana jest ich wyktadnia rozszerzajaca. Wobowiazujacym porzadku prawnym brakuje definicji legalnej, m.in. budżetu zadaniowego, budżetowania zadaniowego, wydatku, które to pojęcia maja istotne znaczenie w odniesieniu do omawianych instytucji. W opracowaniu zastosowano różne metody badawcze: prawnoporównawcza, dogmatycznoprawna, analityczna, które zostały wykorzystane $w$ odniesieniu do właściwych merytorycznie aktów prawnych, orzeczeń organów orzekajacych $w$ sprawach o naruszenie dyscypliny finansów publicznych oraz sadów administracyjnych, a także literatury przedmiotu. W opracowaniu uwzględniono stan prawny obowiązująy na dzień 24 lutego 2017 roku.
\end{abstract}

Słowa kluczowe: budżet zadaniowy, dyscyplina finansów publicznych.

Nadesłany: 25.02.17 | Zaakceptowany do druku: 23.12.17

\section{Performance budget and violation of public finance discipline in related to public expenditure}

The paper discusses issues related to the institution of public expenditure in performance budget in the context of the law on liability for violation of public finance discipline. The author analyzes performance budget, its objectives and characteristics, stressing that the Polish legal system there is a need to develop the scope of the liability for violation of public finance discipline. In the current state of the law difficult, and sometimes impossible is to punish those responsible for non-compliance related to making public spending included in the relevant performance budget.

\footnotetext{
Wojciech Bożek - dr, Uniwersytet Szczeciński, Katedra Prawa Finansowego, Wydział Prawa i Administracji.

Adres do korespondencji: Uniwersytet Szczeciński, Katedra Prawa Finansowego, Wydział Prawa

i Administracji, ul. Narutowicza 17a; 70-240 Szczecin, e-mail: wojciech.bozek@wpiaus.pl.
} 
The study used different research methods: a comparative legal, dogmatic, analytical, which has been used in relation to the relevant substantive laws, judgments adjudicating bodies in cases of violation of public finance discipline and administrative courts, as well as literature. The study takes into account the legal status on February 24, 2017.

Keywords: performance budget, discipline of public finances.

Submitted: 25.02.17 | Accepted: 23.12.17

JEL: K39

\section{Wprowadzenie}

Budżet zadaniowy jest narzędziem wspierającym stabilność finansów publicznych i ważnym elementem reformowania systemu finansów publicznych w kierunku ich unowocześnienia oraz usprawnienia. Dlatego też uznać można, że jedną z metod poprawiania jakości usług publicznych, uzyskiwania $\mathrm{z}$ danych nakładów najlepszych efektów, powiązaną z udostępnianiem obywatelom zrozumiałej informacji na temat funkcjonowania administracji publicznej jest budżetowanie zadaniowe (Postuła i Perczyński, 2010, s. 34), którego immanentną cechą jest planowanie wieloletnie. Mimo że budżet zadaniowy jest stosunkowo nową instytucja prawa finansowego, to opiera się on także na tradycyjnych zasadach budżetowych obowiązujących w polskim porządku finansowoprawnym od wejścia w życie przepisów ustawy $\mathrm{z}$ dnia 26 listopada 1998 r. o finansach publicznych ${ }^{1}$, a w niektórych przypadkach nawet wcześniej. Są to m.in. zasada jawności, uprzedniości, roczności, jedności materialnej i formalnej (Lubińska, 2009, s. 88). Słusznie zauważa U. Zawadzka-Pąk (2014), że w ramach budżetu zadaniowego powiązania planowania zadaniowego z programowaniem wieloletnim mogą być dwojakiego rodzaju, tzn. zachodzą one zarówno poprzez wydłużenie horyzontu planowania $\mathrm{w}$ ustawie budżetowej oraz w załącznikach z nią związanych, jak i poprzez opracowanie odrębnych od budżetu planów o charakterze wieloletnim, odwołujących się jednak do ustawy budżetowej, w której określone zostały w sposób dyrektywny wydatki dokonywane w ciągu roku. Należy mieć na uwadze, że w załącznikach do ustawy budżetowej zamieszcza się m.in. zestawienie programów wieloletnich w układzie zadaniowym.

Warto zauważyć, że aktualnie ponad 50 państw na świecie stosuje budżet zadaniowy, choć forma i zakres jego stosowania są różne. Przykładowo budżet zadaniowy stosowany jest ( $\mathrm{z}$ wyłączeniem wydatków parlamentu) m.in. we Francji, Włoszech, Hiszpanii, Finlandii, Słowacji, w Czechach i Holandii i na Litwie (Osmańska, 2017).

Wraz z wprowadzeniem do polskiego porządku finansowoprawnego ww. instytucji powinny być dokonane zmiany w przepisach ustaw nierozerwalnie powiązanych z ustawą z dnia 27 sierpnia 2009 r. o finansach publicznych ${ }^{2}$, w której uregulowano podstawowe zagadnienia odnoszące się m.in. do zasad i trybu sporządzania budżetu państwa w układzie zadaniowym. Tymczasem w ustawie z dnia 17 grudnia 2004 r. o odpowiedzialności za naruszenie dyscypliny finansów publicznych ${ }^{3}$ nie dokonano żadnej zmiany, umożliwiającej skuteczne egzekwowanie odpowiedzialności osób, które naruszyły podstawowe zasady prawidłowej gospodarki finansowej w zakresie dokonywania wydatków publicznych w układzie zadaniowym budżetu. Powyższe stwierdzenie, w ocenie autora, czyni dyskusję na temat budżetu zadaniowego i potrzeby jego uwzględnienia w u.o.n.d.f.p. aktualną i niezbędną.

\section{Istota budżetu zadaniowego i układu zadaniowego}

Budżet zadaniowy jest planem wydatków budżetowych o szczególnej formie prawnej, sporządzanym w układzie zadaniowym, tzn. funkcji, zadań i podzadań, wraz ze wskazaniem na poziomie zadań i podzadań celów, które planuje się osiągnąć w wyniku realizacji zadania czy też podzadania oraz mierników określających stopień realizacji celów. Nie budzi wątpliwości, że budżet zadaniowy stanowi narzędzie o szczególnej mocy (np. uprawnia do dokonywania wydatków) i szczególnym okresie obowiązywania (zasada roczności) w celu sprawnego zarządzania zadaniami publicznymi, 
które może być wykorzystane do poprawy efektywności oraz skuteczności zarządzania dana jednostka sektora finansów publicznych. Obowiązek prowadzenia budżetu w układzie zadaniowym nie dotyczy jednostek samorządu terytorialnego, a jest realizowany jedynie w budżecie państwa. Nie wyłącza to jednak możliwości korzystania $\mathrm{z}$ omawianej instytucji również przez samorządowe jednostki sektora finansów publicznych na zasadzie dobrowolności (Korolewska i Marchewka-Bartkowiak, 2013, s. 163)

Nawiązując do dorobku literatury międzynarodowej z zakresu prawa finansowego, należy wskazać, że budżetowanie zadaniowe stanowiło efekt dążenia do „uzdrowienia” finansów publicznych. Duże znaczenie w promowaniu budżetu zadaniowego na świecie miały reformy przeprowadzone w latach 40. i 50. XX w. w Stanach Zjednoczonych Ameryki Północnej. Szybko jednak okazało się, że wypracowane w USA rozwiazania były dostosowywane do własnej struktury finansów publicznych i politycznych wymagań rządzących w innych krajach na świecie (Godek-Brunel i Carpentier, 2011, s. 61, 62). Przykładowo, budżet zadaniowy jest definiowany jako budżet, który „określa główny cel lub cele, do których przypisane są środki finansowe. Następnie określane są cele operacyjne, pomiędzy które dzielone sa środki" (Harrison, 2003, za: Godek-Brunel i Carpentier, 2011). Z kolei budżet zadaniowy w Wielkiej Brytanii ma na celu dostarczenie wspomagajacych proces opracowania projektu budżetu informacji o efektywności, a zatem ma charakter prezentacyjny (Zawadzka-Pąk, 2011, s. 167). Cechą wspólną wszystkich definicji podawanych przez ww. autorów jest jednak to, że zawierają hierarchizację celów, a także mierników pozwalających na ewaluację rezultatów polityk publicznych (Godek-Brunel i Carpentier, 2011, s. 61, 62).

W rozumieniu art. 2 pkt 3 ustawy o finansach publicznych układem zadaniowym jest zestawienie odpowiednio wydatków budżetu państwa lub kosztów jednostki sektora finansów publicznych sporządzone według funkcji państwa, oznaczających poszczególne obszary działań państwa, oraz zadań budżetowych grupujących wydatki według celów, a także podzadań budżetowych grupujących działania umożliwiające realizację celów zadania, w ramach którego podzadania te zostały wyodrębnione wraz z opisem celów tych zadań i podzadań, a także $\mathrm{z}$ bazowymi i docelowymi miernikami stopnia realizacji celów działalności państwa. Miernikami są wartościowe, ilościowe lub opisowe określenia bazowego i docelowego poziomu efektów z poniesionych nakładów. Niektóre jednostki sektora finansów publicznych, takie jak agencje wykonawcze, instytucje gospodarki budżetowej, państwowe fundusze celowe oraz państwowe osoby prawne, o których mowa w art. 9 pkt 14 ustawy o finansach publicznych, sporządzają plany finansowe w układzie zadaniowym na rok budżetowy i dwa kolejne lata. Podstawowe znaczenie dla budżetu zadaniowego ma wspomniana wyżej ustawa o finansach publicznych, jednakże omawiajac krajowe podstawy materialnoprawne budżetu zadaniowego ww. jednostek sektora finansów publicznych nie sposób pominąć Rozporządzenia Ministra Finansów w sprawie szczególowego sposobu, trybu i terminów opracowania materiałów do projektu ustawy budżetowej na rok $2017 \mathrm{z}$ dnia 20 maja 2016 roku${ }^{4}$. Na Ministrze Finansów spoczywa ustawowy obowiązek ogólnej kontroli efektywności i skuteczności realizacji budżetu w układzie zadaniowym, co ma istotne znaczenie dla pomiaru uzyskanych efektów wydatkowania środków publicznych (tzw. część sprawnościowa budżetu zadaniowego).

O znaczeniu układu zadaniowego świadczą również rozwiązania proceduralne, odnoszace się do rocznego sprawozdania z wykonania ustawy budżetowej, ponieważ Rada Ministrów przedstawia Sejmowi i Najwyższej Izbie Kontroli, w terminie do dnia 31 maja roku następnego, roczne sprawozdanie $\mathrm{z}$ wykonania ustawy budżetowej oraz m.in. informację o wykonaniu wydatków w układzie zadaniowym. Informacja o wykonaniu wydatków w układzie zadaniowym, z wyodrębnieniem wydatków na programy wieloletnie, powinna zawierać omówienie zarówno realizacji Wieloletniego Planu Finansowego Państwa w zakresie, w jakim określa on cele wraz z miernikami stopnia ich realizacji w układzie obejmującym główne funkcje państwa, jak i omówienie i zestawienie planowanych i poniesionych wydatków oraz planowanych i osiągniętych wartości mierników stopnia realizacji celów sporządzane w układzie zadań budżetowych. 
Podsumowując: budżet zadaniowy jest nowoczesną formą zarządzania finansami publicznymi, obejmującą system planowania, wykonywania i sprawozdawczości. Co istotne, funkcją omawianej instytucji jest wyposażenie budżetu zadaniowego w tzw. część sprawnościową, określającą dla każdego zadania cele jego realizacji oraz mierniki pozwalające monitorować realizację celów.

Warto zasygnalizować, że proces implementacji budżetu zadaniowego na grunt praktycznego jego stosowania jest pracochłonny, czasochłonny i uwarunkowany wieloma czynnikami. W Polsce proces wdrażania budżetu zadaniowego powiązany był w pierwszej kolejności z sektorem samorządowym, ponieważ w latach 1994/1995 został on przygotowany przez miasto Kraków. Z państwowego punktu widzenia istotne znaczenie miało przystąpienie Polski do Unii Europejskiej. W pierwszym kwartale 2006 r. W Departamencie Budżetu Zadaniowego w Kancelarii Prezesa Rady Ministrów podjęto działania mające na celu implementację na grunt polskiego porządku prawnego budżetu zadaniowego, którego walory doceniały najważniejsze instytucje i organizacje światowe, np. Międzynarodowy Fundusz Walutowy, OECD, Bank Światowy, Organizacja Narodów Zjednoczonych). Budżet zadaniowy miał być po raz pierwszy stopniowo wprowadzany w 2009/2010 r. przy czym w 2011 r. zakładano, że budżet państwa będzie przygotowany wyłącznie w układzie zadaniowym. Istotne znaczenie dla wdrożenia rozwiązań odnoszących sie do budżetu zadaniowego miał również Departament Reformy Finansów Publicznych w Ministerstwie Finansów, do którego przeniesiono prace wdrożeniowe. Zgodnie Z nowym planowaniem na lata 2008-2015 w 2013 r. budżet w układzie zadaniowym miał być zaprezentowany w ustawie budżetowej równolegle $\mathrm{z}$ budżetem tradycyjnym (Misiąg, 2013).

\section{Wybrane problemy dochodzenia odpowiedzialności za naruszenie dyscypliny finansów publicznych powiazzane $z$ budżetem zadaniowym}

W pierwszej kolejności należy podkreślić, że dyscyplina finansów publicznych nie odnosi się do sfery makroekonomicz- nej, która znajduje swoje odzwierciedlenie w ograniczeniach dotyczących deficytu sektora finansów publicznych i długu publicznego. Dlatego też uzasadnione jest uznanie, że w zakresie przedmiotowym w u.o.n.d.f.p. zostały pominięte procesy związane z gromadzeniem środków publicznych i ich rozdysponowaniem w skali makroekonomicznej (Drwiłło i Maśniak, 2009, s. 97; Walasik, 2011).

Obecne rozwiazania u.o.n.d.f.p. nie są kompleksowe. W ustawach powiązanych $\mathrm{z}$ u.o.n.d.f.p., takich jak np. ustawa o finansach publicznych, dokonywane sa liczne zmiany, które jednocześnie wiążą się z koniecznościa podjeccia adekwatnych działań związanych z nowym określeniem znamion niektórych czynów stanowiących naruszenie dyscypliny finansów publicznych. Przykładowo potrzeba taka dostrzegana jest w odniesieniu do zachowań dotyczacych omawianego budżetu zadaniowego (Walasik, 2011). Analiza obowiązujących przepisów szeroko pojętego prawa finansowego prowadzi do wniosku, że wiele działań, które mimo że zakłócają realizacje budżetu zadaniowego, nie będą mogły stać się przedmiotem postępowania w sprawach o naruszenie dyscypliny finansów publicznych.

Zanim jednak zostaną omówione poszczególne przykłady w podniesionym wyżej zakresie, konieczne jest nawiązanie do definicji wydatku publicznego w u.o.n.d.f.p. i ustawie o finansach publicznych.

W przepisach prawa regulujących naruszenie dyscypliny finansów publicznych nie sformulowano bowiem legalnej definicji „wydatku”, zaś ustawodawca w u.o.n.d.f.p. przy wykładni tego pojęcia odsyła do znaczenia nadanego mu w ustawie o finansach publicznych (Ruśkowski i Salachna, 2006, s. 7, 11). Podstawowym zarzutem wynikajacym z ww. odesłania do ustawy o finansach publicznych jest to, że definicja wydatku wynikajaca $\mathrm{Z}$ przepisów ww. aktu prawnego jest definicją zakresowo niepełną, a to z kolei powoduje, że wielokrotnie jej stosowanie nie będzie jednoznaczne (Ruśkowski i Salachna, 2006, s. 7, 11). W orzeczeniu Wojewódzkiego Sądu Administracyjnego w Warszawie (Wyrok WSA z 10 lipca 2012 r.) wskazano, że wydatek definiować należy zgodnie $\mathrm{z}$ ekonomicznym rozumieniem tego terminu, czyli jako rozchód środków pieniężnych z kasy lub z rachunku bankowego, tj. rzeczywisty wypływ środków 
z jednostki. W orzeczeniu Głównej Komisji Orzekającej w sprawach o naruszenie dyscypliny finansów publicznych (dalej: GKO) z dnia 28 lipca 2011 r. (Orzeczenie GKO z 28 lipca 2011 r.) wskazano natomiast, że wydatkowanie środków publicznych oznacza ponoszenie wydatków publicznych i dokonywanie rozchodów budżetowych na podstawie planów finansowych jednostek sektora finansów publicznych oraz w wysokości i trybie właściwym dla poszczególnych tytułów wydatków lub rozchodów, zgodnie $\mathrm{z}$ mechanizmem budżetowym lub pozabudżetowym. Wydatkowanie wiąże się z podejmowaniem przez dysponenta środków publicznych decyzji o ich przeznaczeniu w określonej wysokości i na określony cel oraz jest jednym z procesów składających się na normatywne pojęcie finansów publicznych (Orzeczenie GKO z 26 października 2015 r.)

Można wskazać, że ujęcie wydatków budżetu państwa w układzie zadaniowym nie jest czéścia ustawy budżetowej, co może powodować istotne ograniczenia dla przypisania odpowiedzialności za naruszenie dyscypliny finansów publicznych, szczególnie w odniesieniu do dokonywania zmian $\mathrm{w}$ planie finansowym jednostki w układzie zadaniowym przez kierowników jednostek sektora finansów publicznych. Ograniczone możliwości przypisania odpowiedzialności odnoszą się do działań w zakresie realizowanej przez kierowników kontroli zarządczej oraz dokonywanej przez głównych księgowych wstępnej kontroli operacji gospodarczych w relacji do planu wydatków lub kosztów w układzie zadaniowym, gdzie ustawowym znamieniem naruszenia jest przekroczenie planu wydatków (Walasik, 2013, s. 36). Szerszy zakres możliwości pociągnięcia do odpowiedzialności będzie się wiązał z naruszeniami dotyczącymi realizacji wydatków oraz sporządzania sprawozdań. Dlatego konieczna jest nowelizacja u.o.n.d.f.p., w szczególności przez nowe określenie znamion poszczególnych naruszeń dyscypliny finansów publicznych.

Przykładowo art. 10 u.o.n.d.f.p. stanowi, że naruszeniem dyscypliny finansów publicznych jest dokonanie zmiany $\mathrm{w}$ budżecie lub planie, stanowiącym podstawę gospodarki finansowej jednostki sektora finansów publicznych, bez upoważnienia albo z przekroczeniem zakresu upoważnienia. Nie wiadomo zatem w oma- wianym przypadku, co będzie podstawą gospodarki finansowej jednostki sektora finansów publicznych w rozumieniu ustawy o finansach publicznych, tzn. czy plan finansowy w układzie tradycyjnym, czy w układzie zadaniowym. Jak wynika $\mathrm{z}$ analizy przepisów ustawy o finansach publicznych, plan finansowy w układzie zadaniowym stanowi zestawienie efektów i powiązanych z nimi nakładów, natomiast plan finansowy w układzie tradycyjnym obejmuje zestawienie wydatków według rodzaju działalności w działach i rozdziałach klasyfikacji budżetowej oraz rodzaju wydatków w paragrafach klasyfikacji budżetowej. Powyższe zagadnienie może wywoływać istotne wątpliwości interpretacyjne, które będą negatywnie wpływać na efektywne stosowanie narzędzi systemu odpowiedzialności za naruszenie dyscypliny finansów publicznych.

Ponadto konieczność dokonania nowelizacji dotyczy również czynu określonego $\mathrm{w}$ art. 11 u.o.n.d.f.p., zgodnie $\mathrm{z}$ którym naruszeniem dyscypliny finansów publicznych jest dokonanie wydatku ze środków publicznych bez upoważnienia określonego ustawą budżetową, uchwałą budżetową lub planem finansowym albo z przekroczeniem zakresu tego upoważnienia lub z naruszeniem przepisów dotyczących dokonywania poszczególnych rodzajów wydatków. Wątpliwości interpretacyjne będą w tym przypadku dotyczyć stwierdzenia „dokonania wydatku (...) z naruszeniem przepisów dotyczących poszczególnych rodzajów wydatków." Wprowadzenie do systemu finansów publicznych budżetu zadaniowego sporządzanego w układzie zadaniowym może być źródłem wątpliwości, o jakie ujęcie wydatków chodzi, czy wyłącznie obejmujących tradycyjny podział klasyfikacji, czy także układ zadaniowy. Wątpliwości, o których mowa, są o tyle istotne, że naruszenia $z$ art. 11 u.o.n.d.f.p. stanowią trzecia co do liczby najczęściej stwierdzaną grupę naruszeń dyscypliny finansów publicznych w latach 2011-2015. Jedynie naruszenia związane $\mathrm{z}$ przeprowadzeniem i rozliczeniem inwentaryzacji oraz sprawozdawczością, jak również grupa naruszeń w zakresie zamówień publicznych były liczniejsze. $\mathrm{Z}$ danych zawartych w tabeli 1 wynika, że czyny spenalizowane $\mathrm{w}$ art. 11 u.o.n.d.f.p. stanowity grupe od $151 \mathrm{w} 2015$ r. do 333 w 2012 r. naruszeń stwierdzonych przez komisje orzekające w pierwszej instancji w sprawach o naruszenie dyscypliny finan- 
sów publicznych. Udział procentowy ww. naruszeń w ogólnej liczbie stwierdzanych czynów był dynamiczny i wynosił od 10,5\% w 2011 r. do 19,5\% w 2012 roku. Dowodzi to bezsprzecznie doniosłości analizowanych zagadnień i problemów.

Tabela 1. Wybrane naruszenia dyscypliny finansów publicznych stwierdzone przez RKO i ich udział w ogólnej liczbie naruszeń oraz ogólna liczba wybranych naruszeń w latach 2011-2015

\begin{tabular}{|c|c|c|}
\hline \multirow{2}{*}{ Rok } & \multicolumn{2}{|c|}{ art. 11 u.o.n.d.f.p. } \\
\cline { 2 - 3 } & $\begin{array}{c}\text { ogólna liczba naruszeń } \\
\text { w komisjach pierwszej instancji }\end{array}$ & $\begin{array}{c}\text { udział procentowy } \\
\text { we wszystkich czynach w roku }\end{array}$ \\
\hline 2011 & 183 & 10,5 \\
\hline 2012 & 333 & 19,5 \\
\hline 2013 & 210 & 17,1 \\
\hline 2014 & 145 & 14,4 \\
\hline 2015 & 151 & 13,2 \\
\hline
\end{tabular}

Źródło: opracowanie własne na postawie sprawozdań z działalności Głównej Komisji Orzekającej w Sprawach o Naruszenie Dyscypliny Finansów Publicznych oraz zbiorczych sprawozdań z działalności komisji orzekających I instancji w latach 2011-2015, www.mf.gov.pl, dostęp: 24 lutego 2017 r.

Jako ostatni przykład potrzeby doprecyzowania przepisów u.o.n.d.f.p. w związku z wprowadzeniem budżetu zadaniowego w finansach publicznych można wskazać art. 18 pkt 2 u.o.n.d.f.p., zgodnie z którym naruszeniem dyscypliny finansów publicznych jest niesporządzenie lub nieprzekazanie $\mathrm{w}$ terminie sprawozdania $\mathrm{z}$ wykonania procesów gromadzenia środków publicznych i ich rozdysponowania albo wykazanie w tym sprawozdaniu danych niezgodnych z danymi wynikajacymi z ewidencji księgowej. Należy w tym miejscu podkreślić wyraźnie odmienne stanowiska prezentowane w orzecznictwie GKO, a odnoszace się do tego, czy użyte w art. 18 pkt 2 u.o.n.d.f.p. wyrażenie „sprawozdanie z wykonania procesów gromadzenia środków publicznych i ich rozdysponowania" jest tożsame $\mathrm{z}$ pojęciem „sprawozdanie budżetowe". W orzeczeniu GKO z dnia 12 września 2011 r. (Orzeczenie GKO z dnia 12 września 2011 r.), podobnie jak w orzeczeniu GKO z dnia 3 października 2013 r. (Orzeczenie GKO z dnia 3 października 2013 r.), uznano, że istnieje tożsamość między ww. pojęciami. Z kolei w orzeczeniu GKO z dnia 21 lutego 2011 r. (Orzeczenie GKO z dnia 21 lutego 2011 r.) uznano, że „sprawozdanie z wykonania procesów gromadzenia środków publicznych i ich rozdysponowania" jest pojęciem szerszym od wcześniej obowiązującego i definiowanego jako „sprawozdanie budżetowe”. Wska- zana wyżej rozbieżność może w komisjach orzekających w sprawach o naruszenie dyscypliny finansów publicznych wywoływać wątpliwości interpretacyjne, dotyczące zwrotu: „niesporządzenie lub nieprzekazanie $\mathrm{w}$ terminie sprawozdania $\mathrm{z}$ wykonania procesów rozdysponowania środkami publicznymi". Nie wiadomo bowiem, jak szeroko w postępowaniu prowadzonym na podstawie u.o.n.d.f.p. skład komisji orzekającej będzie pojmował „rozdysponowanie środków publicznych", tj. czy interpretacja zostanie ograniczona do wydatków wyłącznie w układzie zadaniowym i np. naruszenia przepisów Rozporządzenia Ministra Finansów w sprawie sprawozdawczości budżetowej w układzie zadaniowym z dnia 28 grudnia 2011 r. ${ }^{5} \mathrm{w}$ zW. z art. 41 ust. 4 ustawy o finansach publicznych, czy też obejmować będzie również sprawozdania z innych operacji finansowych, a jeżeli tak, to jakich konkretnie sprawozdań. Znane są bowiem również orzeczenia GKO, w których wyrażone są wątpliwości, czy np. sprawozdania $\mathrm{Rb}-\mathrm{N}$ i Rb-NDS są sprawozdaniami „z wykonywania procesów gromadzenia środków publicznych i ich rozdysponowania", o których mowa w art. 18 pkt 2 u.o.n.d.f.p. Powyższy problem był również interpretowany w piśmie Ministerstwa Finansów, Biura Dyscypliny Finansów Publicznych, znak: BDF1/033/12/ HKA $/ 11 / 4352^{6}$, w którym podkreślono, że zgodnie z u.o.n.d.f.p. wiążącej, w danej 
sprawie o naruszenie dyscypliny finansów publicznych, wykładni prawa dokonują komisje orzekające w sprawach o naruszenie dyscypliny finansów publicznych dopiero po złożeniu przez rzecznika dyscypliny finansów publicznych wniosku o ukaranie konkretnej osoby za konkretne działanie lub zaniechanie. „O ile bowiem naruszenie polegające na nieterminowym przekazaniu sprawozdania niewątpliwie może dotyczyć wszystkich sprawozdań, o tyle wydaje się, że wykazanie w sprawozdaniu danych niezgodnych $\mathrm{z}$ danymi wynikającymi $\mathrm{z}$ ewidencji księgowej nie będzie dotyczyło sprawozdań zbiorczych czy laccznych sporządzanych nie na podstawie danych księgowych, lecz na bazie sprawozdań jednostkowych przedstawianych przez jednostki niższego szczebla"7. Mając powyższe na uwadze, należy jeszcze podkreślić, że kryterium kontroli w budżecie zadaniowym jest nie tylko legalność (zgodność z prawem) dokonywania wydatków, która powinna wynikać z ww. sprawozdań, ale również skuteczność i efektywność działania jednostek administracji publicznej.

\section{Podsumowanie}

Budżet sporządzany z wykorzystaniem tradycyjnych podziałek klasyfikacji budżetowej (części, działy, rozdziały i paragrafy) nie uwzględnia celowości i skuteczności ponoszonych wydatków, ich wpływu na rzeczywistość społeczno-gospodarcza (Osmańska, 2017). Budżet zadaniowy sprzyja z kolei osiąganiu większej skuteczności realizacji zadań publicznych, jak również transparentności finansów publicznych, dzięki czemu obywatelom dostarcza się przejrzystych i czytelnych informacji na temat podejmowanych działań i ich kosztów. Budżetowanie zadaniowe prowadzi również do zwiększenia efektywności wydatkowania środków publicznych i wobec powyższego można uznać, że jest to istotne narzędzie usprawniające procesy, składające się na finanse publiczne, a związane np. z rozdysponowywaniem środków publicznych. Budżetowanie zadaniowe powiązane jest z zarządzaniem wydatkami publicznymi w sposób skuteczny, efektywny, transparentny oraz z uwzględnieniem kilkuletniej jego projekcji, tzn. planowania wieloletniego. Pomimo ewidentnych korzyści płynących z budżetu zadaniowego dla zapewnienia ładu i bezpieczeństwa w finansach publicznych, w słowniku ustawowym u.f.p. nie został zdefiniowany ani budżet zadaniowy, ani budżetowanie zadaniowe, których elementem jest układ zadaniowy (Frysztak i Nowak-Far, 2017). Stan taki należy ocenić krytycznie, ponieważ przepisy ustawy o odpowiedzialności za naruszenie dyscypliny finansów publicznych nie mogą być przedmiotem wykładni rozszerzającej.

$\mathrm{Z}$ definicji układu zadaniowego $\mathrm{z}$ art. 2 pkt 3 ustawy o finansach publicznych wynika, że efekty pracy administracji publicznej oceniane są za pomocą realizacji wyznaczonych celów, a także z wykorzystaniem bazowych i docelowych mierników stopnia realizacji celów działalności państwa. W literaturze przedmiotu podkreśla się nieprawidłowość ww. definicji wynikajaca $\mathrm{z}$ wystepujacego $\mathrm{w}$ niej błedu ignotum per ignotum, ze względu na braki definicyjne pojecć wykorzystanych w art. 2 pkt 3 u.f.p. „Nie zostały bowiem w niej zdefiniowane pojecia wykorzystane w definicji układu zadaniowego: funkcje państwa, obszary działania państwa czy też zadania, podzadania budżetowe i cele tych zadań. Nie zostały też określone sposoby weryfikacji faktu realizacji zamierzonych zadań i sposobu ich urzeczywistnienia oraz sposoby kontroli takiej weryfikacji" (por. Frysztak i Nowak-Far, 2017 i wskazana tam literatura). Będzie to miało również znaczenie w odniesieniu do przepisów ww. ustawy o odpowiedzialności za naruszenie dyscypliny finansów publicznych.

Uwzględniając aktualne rozwiązania prawne w zakresie odpowiedzialności za naruszenie dyscypliny finansów publicznych, można stwierdzić, że w polskim porządku prawnym brakuje instrumentów efektywnej ochrony środków publicznych przed czynami naruszającymi zasady związane $\mathrm{z}$ budżetowaniem zadaniowym i planowaniem wieloletnim. Czyny, o których mowa, jako szkodliwe dla sektora finansów publicznych, zagrażają ładowi i bezpieczeństwu finansów publicznych. $\mathrm{Z}$ przeprowadzonej analizy sprawozdań z działalności Głównej Komisji Orzekajacej w sprawach o naruszenie dyscypliny finansów publicznych oraz komisji orzekających w pierwszej instancji wynika, że naruszenia w omawianym zakresie w latach 2011-2015 zdarzały się często, plasując się na trzecim miejscu, jeżeli chodzi o kategorię najliczniej stwierdzanych czynów określonych w u.o.n.d.f.p. 
Dowodzi to potrzeby doprecyzowania przepisów prawnych pod kątem ochrony środków publicznych przed ewentualnymi naruszeniami związanymi z budżetowaniem zadaniowym i programowaniem wieloletnim. Podkreślić należy, że na podstawie u.o.n.d.f.p. wobec osoby obwinionej nie można wyciągnąć negatywnych konsekwencji w sytuacji, w której kilka przepisów pozostaje ze sobą w sprzeczności, albo istnieją poważne trudności w jednoznacznym wyinterpretowaniu normy prawnej (Orzeczenie GKO z dnia 9 czerwca 2011 r.).

W podsumowaniu należy podkreślić, że odpowiedzialność za naruszenie dyscypliny finansów publicznych ponosi osoba, która popełniła czyn naruszający dyscyplinę finansów publicznych określony przez ustawę obowiązującą w czasie jego popełnienia. W aktualnym stanie prawnym naruszenia, o których mowa w rozdziale poświęconym analizie u.o.n.d.f.p. nie odnosiłyby się do niektórych jednostek sektora finansów publicznych, takich jak jednostki samorządu terytorialnego, bowiem przepisy ustawy o finansach publicznych ani inne akty prawne w żadnej mierze nie przewidują obowiązku prowadzenia przez organ stanowiący jednostki samorządu terytorialnego, poza tzw. budżetem tradycyjnym, budżetu zadaniowego (Korolewska i Marchewka-Bartkowiak, 2013, s. 163 oraz por. Walczak, 2017).

Warto również wskazać, że na temat stanu wdrażania układu zadaniowego budżetu państwa, zanim jeszcze proces ten został zakończony, wypowiedziała się Najwyższa Izba Kontroli w dokumencie pt. Wdrażanie budżetu państwa w uktadzie zadaniowym - ocena procesów: planowania, monitorowania i sprawozdawczości, Informacja o wynikach kontroli, wskazując, że: „Skutecznemu wdrażaniu nie sprzyjają także niespójności systemu prawnego, w szczególności w obszarze odpowiedzialności organów władzy publicznej za merytoryczną realizację i finansowanie zadań publicznych”, a ponadto, że „w obecnym stanie wdrożenia budżet zadaniowy stanowi dodatkową, oprócz tradycyjnej, klasyfikację wydatków państwa, nie wnoszącą żadnej wartości dodanej zwłaszcza w aspekcie zarządczym" (Najwyższa Izba Kontroli, 2012, s. 7,15).

Nie można nie wspomnieć również o tym, że nowy sposób budżetowania zadaniowego to nie tylko końcowy doku- ment, ale system planowania, wykonywania i sprawozdawczości odnoszący się do wydatków. System, o którym mowa wyżej, z punktu widzenia przepisów u.o.n.d.f.p. powinien zmierzać do precyzyjnego określenia zadań, które mają być finansowane ze środków budżetowych, a także stosowania odpowiednich podziałek klasyfikacyjnych, które umożliwiałyby ocenę efektów uzyskanych w wyniku ponoszonych wydatków budżetowych. W u.o.n.d.f.p. powinny zatem - w ślad za zmianami ustawowymi w innych aktach prawnych - wejść również rozwiązania piętnujące zachowania zmierzające do wydatkowania środków publicznych niezgodnie z zadaniowym ujęciem. Odpowiedzialnością, o której mowa wyżej, pod względem zakresu przedmiotowego, powinno objąć się czyny naruszające ład i bezpieczeństwo wydatkowania środków publicznych zarówno na etapie planowania, wykonania, jak i sprawozdawczości. Ważne będzie również dokonanie zmian w aktualnie obowiązujących przepisach u.f.p. odnoszących się np. do kontroli zarządczej, tak aby zapewnić koordynację zestawień mierników wykonania zadań i planowanych wartości tych mierników: w budżecie zadaniowym, a więc w układzie funkcji państwa oraz w planach działalności dla działów administracji rządowej (Misiąg, 2013). Istota budżetowania zadaniowego sprowadza się bowiem do lepszej alokacji zasobów finansowych i rzeczowych, a w rezultacie właściwszego zaspokajania zbiorowych potrzeb społeczeństwa w celu związania wydatków z efektami, jakim mają one służyć. Odnosi się to zatem do wszystkich etapów związanych $\mathrm{z}$ rozdysponowaniem środków publicznych.

Wdrożenie budżetowania zadaniowego nie jest zadaniem latwym ze względu na istnienie różnych barier, które wpływają na tempo i zakres wdrażanych zmian. Niektóre z barier mają charakter normatywny: niedostosowanie u.f.p. do budżetowania zadaniowego, inne - organizacyjny, np. brak koordynacji zadań poszczególnych resortów przy wdrażaniu budżetowania zadaniowego, czy też mentalny: niechęć administracji do wdrażania nowych metod i do poddawania się dodatkowym procedurom kontrolnym (Misiąg, 2013). Doceniając jednak walory budżetu zadaniowego, trzeba stwierdzić, że troska o prawidłowe gospodarowanie środkami publicznymi powinna uzasadniać podejmowanie, choćby 
niewielkich, kroków ku pełnemu wdrożeniu budżetu zadaniowego.

Należy wskazać, że nie został jeszcze wypracowany jeden idealny model budżetu zadaniowego. Przykładowo model francuski jest uznawany za mniej skomplikowany, ale za to upolityczniony.

\section{Przypisy}

1 Ustawa z dnia 26 listopada 1998 r. o finansach publicznych, tj. Dz.U. z 2003 nr 15, poz. 148 ze zm.

2 Ustawa z dnia 27 sierpnia 2009 r. o finansach publicznych, tj. Dz.U. z 2016 r. poz. 1870 ze zm. dalej: ustawa o finansach publicznych.

3 Ustawa z dnia 17 grudnia 2004 r. o odpowiedzialności za naruszenie dyscypliny finansów publicznych, tj. Dz.U. z 2013 r., poz. 168 ze zm. dalej: u.o.n.d.f.p.

4 Rozporządzenie Ministra Finansów w sprawie szczegółowego sposobu, trybu i terminów opracowania materiałów do projektu ustawy budżetowej na rok 2017 z dnia 20 maja 2016 r., Dz.U z 2016 r. poz. 735

5 Rozporządzenie Ministra Finansów w sprawie sprawozdawczości budżetowej w układzie zadaniowym z dnia 28 grudnia 2011 r., Dz.U. Nr 298, poz. 1766.

6 Biuletyn Informacyjny Regionalnej Izby Obrachunkowej w Bydgoszczy Nr 2 (74) 2012 s. 64-65, www.bydgoszcz.rio.gov.pl, dostęp: 24.02.2017.

7 Ibidem, s. 65

\section{Bibliografia}

Drwiłło, A. i Maśniak, D. (red.) (2009). Leksykon prawa finansowego. Warszawa: C.H. Beck.

Frysztak, M. i Nowak-Far, A. (2017). Komentarz do art. 2 u.f.p. W: W. Misiąg W. (red.), Ustawa o finansach publicznych. Ustawa o odpowiedzialności za naruszenie dyscypliny finansów publicznych. Komentarz, 2017, Legalis (dostep: 15.12.2017 r.) za: Dzwonkowski, H. (red.), Ustawa o finansach publicznych, komentarz do art. 2.

Godek-Brunel, M. i Carpentier, S. (2011). Wybrane problemy opracowania i wdrażania mierników we francuskim budżecie zadaniowym. W: E. Ruśkowski (red.), Instrumenty nowego zarzadzania finansami publicznymi w wybranych krajach Unii Europejskiej, Białystok: Temida 2.

Korolewska, M. i Marchewka-Bartkowiak, K (2013). Budżet zadaniowy w samorządach terytorialnych - analiza wyników badania ankietowego oraz studium przypadków na przykładzie miast na prawach powiatu. W: K. Marchewka-Bartkowiak i Z. Szpringer (red.), Budżet zadaniowy. Studia $B A S, 1(33)$.
Lubińska, T. (2009). Budżetowanie zadaniowe w kontekście zasad podatkowych i budżetowych. W: S. Wieteska i M. Wypych (red.), W poszukiwaniu efektywności finansów publicznych. Łódź: Wydawnictwo Uniwersytetu Łódzkiego.

Misią, W. (2013). Siedem lat wdrażania budżetu zadaniowego - refleksje i prognozy. W: K. Marchewka-Bartkowiak i Z. Szpringer (red.), Budzet zadaniowy, Studia BAS 1(33).

Osmańska, M. (2017). Komentarz do art. 2 u.f.p. W: A. Mikos-Sitek i R. Bucholski (red.), Ustawa $o$ finansach publicznych. Komentarz, Legalis (dostęp: 15.12.2017).

Postuła, M. i Perczyński, P. (2010). Budżet zadaniowy - wprowadzenie; znaczenie wieloletniego planowania strategicznego $w$ procesie budżetowania. Warszawa: Difin.

Ruśkowski, E. i Salachna, J.M. (2006). Wpływ zmian regulacji zasad publicznej gospodarki finansowej na odpowiedzialność za naruszenie dyscypliny finansów publicznych. Finanse Komunalne, 10.

Walasik, A. (2013). Odpowiedzialność za naruszenie dyscypliny finansów publicznych w zakresie budżetu zadaniowego. Państwo i Prawo, 10, 36.

Walasik, A. (2011). Dyscyplina finansów publicz nych w aspekcie racjonalizacji wydatków publicznych. Polskie Towarzystwo Ekonomiczne. Zeszyty Naukowe, 10, 55-56.

Walczak, P. (2017). Komentarz do art. 2 u.f.p. W P. Walczak (red.), Ustawa o finansach publicznych. Komentarz dla jednostek samorzadowych. Warszawa Legalis (dostęp: 15.12.2017).

Zawadzka-Pąk, U. (2014). Budżetowanie zadaniowe a programowanie wieloletnie $\mathrm{w}$ finansach publicznych. W: E. Ruśkowski (red.), Roczność $i$ wieloletniość $w$ finansach publicznych. Warszawa: Wolters Kluwer Polska.

Zawadzka-Pak, U. (2011). Instrumenty nowego zarządzania finansami publicznymi w Wielkiej Brytanii. W: E. Ruśkowski (red.), Instrumenty nowego zarzadzania finansami publicznymi w wybranych krajach Unii Europejskiej. Białystok: Temida 2.

\section{Akty prawne}

Ustawa z dnia 26 listopada 1998 r. o finansach publicznych, tj. Dz.U. z 2003 nr 15, poz. 148 ze zm.

Ustawa z dnia 17 grudnia 2004 r. o odpowiedzialności za naruszenie dyscypliny finansów publicznych, tj. Dz.U. z 2017 r., poz. 1311 ze zm.

Ustawa $z$ dnia 27 sierpnia 2009 r. o finansach publicznych, tj. Dz.U. z 2017 r. poz. 2077 ze zm.

Rozporządzenie Ministra Finansów w sprawie szczególowego sposobu, trybu i terminów opracowania materiałów do projektu ustawy budżetowej na rok 2017 z dnia 20 maja 2016 r., Dz.U. z 2016 r. poz. 735 . 
Rozporządzenie Ministra Finansów w sprawie sprawozdawczości budżetowej w układzie zadaniowym z dnia 28 grudnia 2011 r., Dz.U. Nr 298, poz. 1766.

\section{Orzeczenia i inne źródła}

Wyrok WSA z 10 lipca 2012 r., V SA/Wa 839/2012, BONDFP 2012, nr 4, poz. 9.

Orzeczenie GKO z 28 lipca 2011 r. BDF1/4900/53/59/11/1638, www.mf.gov.pl, dostęp: 24 lutego 2017 r.

Orzeczenie GKO z 26 października 2015 r. BDF1.4800.103.2015, www.mf.gov.pl, dostęp: 30 kwietnia 2016 r.

Orzeczenie GKO z dnia 12 września 2011 r., BDF1/4900/59/65/11/1852, BNDFP 2011, nr 4, poz. 10.
Orzeczenie GKO z dnia 3 października 2013 r., BDF1/4900/40/45/13/RWPD-39621, LexPolonica nr 8195107, dostęp: 24.02.2017 r.

Orzeczenie GKO z dnia 21 lutego 2011 r., BDF1/4900/131/149/10/3766, LexPolonica nr 2574332, dostęp: 24.02.2017 r.

Orzeczenie GKO z dnia 9 czerwca 2011 r. BDF1/4900/45/51/RN-15/11/1468, LexPolonica nr 2593932, dostęp: 24.02.2017 r.

Biuletyn Informacyjny Regionalnej Izby Obrachunkowej w Bydgoszczy Nr 2 (74) 2012, s. 64-65, www. bydgoszcz.rio.gov.pl, dostęp: 24.02.2017 r.

Najwyższa Izba Kontroli (2012). Wdrażanie budżetu państwa w uktadzie zadaniowym - ocena procesów: planowania, monitorowania $i$ sprawozdawczości, Informacja o wynikach kontroli. Warszawa. 